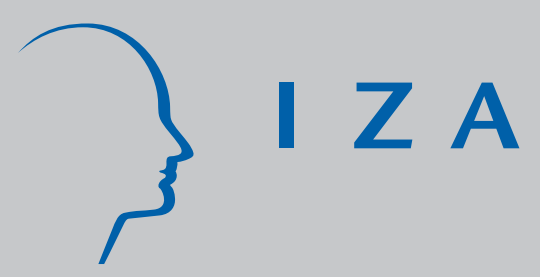

IZADP No. 2861

How Tax Progression Affects Effort and Employment

Erkki Koskela

Ronnie Schöb

J une 2007 


\title{
How Tax Progression Affects Effort and Employment
}

\author{
Erkki Koskela \\ University of Helsinki \\ and IZA
}

Ronnie Schöb

Free University of Berlin

\section{Discussion Paper No. 2861 \\ June 2007}

\author{
IZA \\ P.O. Box 7240 \\ 53072 Bonn \\ Germany \\ Phone: +49-228-3894-0 \\ Fax: +49-228-3894-180 \\ E-mail: iza@iza.org
}

\begin{abstract}
Any opinions expressed here are those of the author(s) and not those of the institute. Research disseminated by IZA may include views on policy, but the institute itself takes no institutional policy positions.
\end{abstract}

The Institute for the Study of Labor (IZA) in Bonn is a local and virtual international research center and a place of communication between science, politics and business. IZA is an independent nonprofit company supported by Deutsche Post World Net. The center is associated with the University of Bonn and offers a stimulating research environment through its research networks, research support, and visitors and doctoral programs. IZA engages in (i) original and internationally competitive research in all fields of labor economics, (ii) development of policy concepts, and (iii) dissemination of research results and concepts to the interested public.

IZA Discussion Papers often represent preliminary work and are circulated to encourage discussion. Citation of such a paper should account for its provisional character. A revised version may be available directly from the author. 


\section{ABSTRACT}

\section{How Tax Progression Affects Effort and Employment ${ }^{*}$}

Within an efficiency wage framework, we study the effects of two revenue-neutral tax reforms that change the progressivity of the labour tax system. A revenue-neutral increase in both the wage tax and tax exemption and a revenue-neutral change in the composition of labour taxation towards the tax with the smaller tax base will lead to the same results: they moderate wages, workers' effort, effective labour input and aggregate output. Whether employment rises or falls, however, depends in both reforms on the magnitude of the prereform total tax wedge. The larger this tax wedge is, the more negative is the impact of reforms on workers' effort. A larger total tax wedge increases the negative effect of tax progression on labour productivity and thus thwarts the positive employment effect of wage moderation.

JEL Classification: $\quad \mathrm{H} 22, \mathrm{~J} 41, \mathrm{~J} 48$

Keywords: efficiency wages, tax progression, structure of labour taxation

Corresponding author:

Erkki Koskela

Department of Economics

University of Helsinki

P.O. Box 17 (Arkadiankatu 7)

00014 Helsinki

Finland

E-mail: erkki.koskela@helsinki.fi

\footnotetext{
* The authors thank the Research Unit of Economic Structures and Growth (RUESG), financed by Academy of Finland, Yrjö Jahnsson Foundation, Bank of Finland and Nokia Group, for financial support. Koskela also thanks Academy of Finland (grant No. 1117698) for further financial support and Otto-von-Guericke University Magdeburg for great hospitality. Comments by Sven Wehke are gratefully acknowledged.
} 


\section{Introduction}

In economies with perfectly functioning labour markets, labour taxation distorts the labour market and lowers employment but does not create involuntary unemployment. When labour market imperfections lead to wage rates above market clearing levels, labour taxes normally aggravate unemployment by widening the gap between the labour cost and the opportunity cost of labour. Recent research has shown that it is not only the magnitude of the tax wedge that matters. The specific structure of labour taxation, in particular the degree of labour tax progression, is also of great importance. The way in which tax progression affects unemployment, however, crucially depends on the particular underlying labour market imperfection.

The analysis of tax progression within the wage bargaining framework and the search and matching framework has shown robust results for several wage bargaining models by demonstrating that an increase in tax progression leads to wage moderation and is good for employment (see, e.g., Koskela and Vilmunen 1996, Holm and Koskela 1996, Koskela and Schöb 1999 and Heijdra and Lighart 2005). The results for efficiency wage models, where firms unilaterally decide upon both the wage rate and the employment level, are, however, still mixed. There, wage moderation has a positive effect on labour demand but a negative effect on individual labour effort and thus workers' productivity. Hoel (1990) was the first to analyze the overall effect of tax progression in such a framework. He shows that a higher marginal income tax rate, which leaves the average tax level unchanged at the initial equilibrium wage rate, will decrease the gross wage and unemployment (see also Goerke 1999). Fuest and Huber (1998) show that, for a rise in tax progression such that the tax burden per worker is the same in the old and new equilibrium, the result might be reversed. Using the Shapiro and Stiglitz (1984) shirking model, Pissarides (1998), in turn, does not find any effect of the tax structure on the wage rate. This is because the individuals' effort decisions in this model are discrete so that workers either shirk or do not shirk. When effort is a continuous 
variable, however, Soerensen (1999) shows that higher tax progression induces wage moderation and lowers both unemployment and work effort (also see Picard and Toulemonde 2003, who derive a similar result in a generic model that allows the analysis of different types of labour market imperfections). All these results do not carry over to models where workers differ in their productivity. A tax reform that raises marginal tax rates at all income levels and increases (decreases) average taxes at high (low) income levels may lead to higher gross wages and unemployment (see Andersen and Rasmussen 1999). Rasmussen (2002) shows that in the long run with free entry and exit of firms when aggregate employment is determined by the zero-profit condition, changes in profits may imply that higher wage tax progressivity will negatively affect employment if the marginal tax rate is high enough. These results cast doubts that tax progression is always good for employment in an efficiency wage framework.

In this paper, we focus on revenue-neutral changes in the degree of tax progression in an efficiency wage model where homogenous workers can choose their optimal work effort level continuously. In doing so, we would like to contribute to the literature in two ways. First, we want to highlight the role of the governmental budget in determining the impact tax progression has on employment. The degree of tax progression not only affects gross wages and workers' outside options, but also affects the way in which the government can substitute payroll taxes for wage taxes or increase tax allowances in a revenue-neutral way. To see this, consider a revenue-neutral tax reform that raises both the marginal wage tax and the tax exemption by initially keeping the wage rate constant. This leads to wage moderation. The higher the total marginal tax wedge, the more this wage moderation reduces tax revenues and the less the government can raise the workers' tax exemption. For any given increase of the marginal tax rate, the effort enhancing effect thus decreases with the total tax wedge. A lower effort level decreases the workers' labour productivity labour, and demand becomes smaller at any given wage rate. If the revenue-neutral rise in the tax exemption becomes very small, the initial positive employment effect may be reversed. 
The second point we want to stress in this paper is as follows. The literature widely ignores the different ways in which the government can vary the degree of tax progression. In addition to changing wage tax progression directly, tax progression is also affected by the way in which labour taxes are levied on workers and firms. The impact of the composition of wage and payroll taxes on progressivity have not yet been analyzed in an efficiency wage framework, ${ }^{1}$ while results from union bargaining models already exist. Koskela and Schöb (1999) show that when tax bases for wage and payroll taxes are equal, it does not matter who de jure pays the tax on labour. In this case the total tax wedge, i.e. the sum of wage and payroll taxes, is sufficient to specify the distortion due to labour taxation. But this equivalence result ceases to hold when the tax bases are not equal because of tax exemptions (see also Koskela and Schöb 2002). A revenue-neutral restructuring of labour taxes towards the narrower tax base then decreases the gross wage and boosts employment. In this paper, we will ask whether these findings concerning the impacts of differences in the structure of labour taxation hold in an efficiency wage framework with non-discrete work effort choice. In particular, we are interested in whether tax progression per se or the specific way in which it is achieved matters for the determination of its employment effects.

After the presentation of some stylized facts about labour taxation and tax progression for OECD countries in terms of wage and payroll taxes in section 2, we develop a model framework that mirrors the stylized facts in section 3 and provide comparative statics of tax parameters on wage setting, work effort, labour demand and aggregate output. Then we separately analyze the two distinct tax-revenue-neutral changes in tax progression. In section 4, we focus on changes in the wage tax progression by varying the marginal wage tax and the

\footnotetext{
${ }^{1}$ One exception is Picard and Toulemonde (2003), who show that, in general, a revenue-neutral shift of a tax on firms to a tax on workers has an incidence on employment (see their proposition 2); tax progressivity, however, is only analyzed in the context of varying wage tax progression (see their proposition 3).
} 
tax exemption. Section 5 then considers how a change in the composition of wage and payroll taxes affect wage setting and employment. Finally we present concluding comments. 
Table 1: Labour taxation in the OECD countries

\begin{tabular}{|c|c|c|c|c|c|c|c|c|c|c|}
\hline Country & $\begin{array}{c}\text { (1) } \\
\text { Average } \\
\text { wage tax }\end{array}$ & $\begin{array}{c}\text { (2) } \\
\text { Social se- } \\
\text { curity contri- } \\
\text { butions paid } \\
\text { by employee }\end{array}$ & $\begin{array}{c}\text { (3) } \\
\text { Marginal } \\
\text { wage tax }\end{array}$ & $\begin{array}{c}\text { (4) } \\
\text { average wage } \\
\text { tax rate } \\
\text { progression }\end{array}$ & \begin{tabular}{|c} 
(5) \\
Social se- \\
curity contri- \\
butions paid \\
by employer
\end{tabular} & $\begin{array}{c}\text { (6) } \\
\text { average } \\
\text { payroll tax } \\
\text { rate } \\
\text { progression }\end{array}$ & \begin{tabular}{|c}
$(7)$ \\
Tax \\
exemption in \\
Euro
\end{tabular} & $\begin{array}{c}\text { (8) } \\
\text { Calculated } \\
a / w\end{array}$ & $\begin{array}{c}(9) \\
b \\
\text { in Euro }\end{array}$ & $\begin{array}{c}(10) \\
\text { Standardized } \\
\text { unemployment } \\
\text { rate } 2004\end{array}$ \\
\hline Australia & 24.3 & 0 & 31.5 & 7.2 & 6.0 & 0.0 & 8,761 & 22.9 & n.a. & 5.5 \\
\hline Austria & 10.8 & 18.0 & 24.6 & 13.8 & 29.0 & -0.2 & 14,931 & 56.1 & 5,057 & 4.8 \\
\hline Belgium & 26.6 & 14.0 & 40.8 & 14.2 & 34.5 & 4.8 & 12,398 & 34.8 & 8,193 & 7.8 \\
\hline Canada & 17.8 & 6.9 & 24.2 & 6.4 & 4.2 & -7.0 & 9,002 & 26.4 & 5,446 & 7.2 \\
\hline Czech Republic & 11.4 & 12.5 & 17.5 & 6.1 & 34.9 & -0.1 & 5,008 & 34.9 & 3,448 & 8.3 \\
\hline Denmark & 30.6 & 10.6 & 38.6 & 8.0 & 0.0 & 0.0 & 7,789 & 20.7 & 11,650 & 5.4 \\
\hline Finland & 24.2 & 6.1 & 38.2 & 14.0 & 24.1 & 0.0 & 10,987 & 36.6 & 4,797 & 8.9 \\
\hline France & 13.1 & 13.6 & 18.8 & 5.7 & 39.3 & 0.1 & 7,719 & 30.3 & 5,092 & 9.7 \\
\hline Germany & 19.6 & 20.9 & 35.6 & 16.0 & 20.8 & 0.1 & 15,822 & 44.9 & 3,872 & 9.5 \\
\hline Greece & 0.6 & 16.0 & 12.6 & 12.0 & 28.0 & 0.0 & 16,464 & 95.2 & n.a. & 10.5 \\
\hline Hungary & 12.4 & 13.5 & 26.0 & 13.6 & 33.6 & -3.2 & 5,059 & 52.3 & 1,547 & 5.9 \\
\hline Iceland & 25.5 & 0.2 & 36.8 & 11.3 & 5.7 & 0.0 & 9,350 & 30.7 & 9,439 & 3.1 \\
\hline Ireland & 10.6 & 5.0 & 21.0 & 10.4 & 10.8 & 0.0 & 13,520 & 49.5 & 6,552 & 4.5 \\
\hline Italy & 18.6 & 9.2 & 34.9 & 16.3 & 33.1 & 0.1 & 12,285 & 46.7 & 4,208 & 8.0 \\
\hline Japan & 5.9 & 11.6 & 11.3 & 5.4 & 12.6 & 0.2 & 14,907 & 47.8 & 7,487 & 4.7 \\
\hline Korea & 2.2 & 7.1 & 11.0 & 8.8 & 8.9 & 0.2 & 26,566 & 80.0 & 5,313 & 3.7 \\
\hline Luxembourg & 8.9 & 13.8 & 25.1 & 16.2 & 12.9 & -0.6 & 20,347 & 64.5 & 11,349 & 4.8 \\
\hline Mexico & 3.0 & 1.5 & 13.7 & 10.7 & 10.7 & -2.2 & 7,110 & 78.1 & n.a. & 2.4 \\
\hline Netherlands & 8.5 & 25.8 & 19.6 & 11.1 & 10.8 & -5.7 & 19,290 & 56.6 & 10,219 & 4.6 \\
\hline New Zealand & 20.7 & 0 & 33.0 & 12.3 & 0.0 & 0.0 & 10,521 & 37.3 & n.a. & 3.9 \\
\hline Norway & 20.9 & 7.8 & 28.0 & 7.1 & 13.0 & 0.0 & 8,424 & 25.4 & 9,966 & 4.4 \\
\hline Poland & 6.1 & 25.4 & 9.2 & 3.1 & 20.4 & 0.1 & 4,846 & 33.7 & 3,020 & 18.8 \\
\hline Portugal & 5.6 & 11.0 & 14.0 & 8.4 & 23.8 & 0.0 & 7,820 & 60.0 & 2,216 & 6.7 \\
\hline Slovak Republic & 7.9 & 13.4 & 16.5 & 8.6 & 35.6 & -0.1 & 5,380 & 52.1 & 1,755 & 18.0 \\
\hline Spain & 12.7 & 6.4 & 22.4 & 9.7 & 30.6 & 0.2 & 9,742 & 43.3 & 6,074 & 10.9 \\
\hline Sweden & 24.0 & 7.0 & 28.9 & 4.9 & 32.7 & 0.0 & 4,422 & 17.0 & 4,172 & 6.4 \\
\hline Switzerland & 9.8 & 11.1 & 18.4 & 8.6 & 11.0 & -0.1 & 16,083 & 46.7 & 7,570 & 4.4 \\
\hline Turkey & 15.4 & 15.0 & 17.6 & 2.2 & 21.4 & 0.0 & 2,058 & 12.5 & 0 & 9.5 \\
\hline United Kingdom & 15.9 & 8.5 & 24.5 & 8.6 & 12.8 & 2.9 & 11,547 & 35.1 & 4,605 & 4.7 \\
\hline United States & 16.5 & 7.7 & 21.3 & 4.8 & 7.7 & 0.1 & 7,872 & 22.5 & 1,747 & 5.5 \\
\hline
\end{tabular}

Source: OECD (2004)

Legend: Tax rates are for the year 2004 for a single person with 100\% of average wage. Column (4) shows the difference between marginal and average rate of income tax. Social security contributions paid by employees are assumed not to be subject to tax exemption. Social security contributions are marginal contributions. As an approximation it is assumed that for each country the tax schedule consists of a tax exemption and a constant marginal tax rate. The exchange rate between US-Dollar and Euro was assumed to be unity. Social assistance levels do not include housing costs. Numbers of social assistance are from 2002 taken from OECD (2004), Benefits and Wages, OECD Indicators. 


\section{Labour taxation and tax progression in OECD countries: stylized facts}

Table 1 lists wage taxes and payroll taxes in the OECD countries, calculated for an average productive worker who is not married. The first and second column report the average income taxes and the social security contributions paid by the employees. The third column shows the marginal income taxes. The fourth column states the average wage tax progression (see Lambert 2001, chapters 7-8). This rate states the difference between the marginal and the average income tax rate due to the tax exemption for wage taxes. The higher this difference, the more progressive wage taxation is. Table 1 shows that all OECD countries have a progressive wage tax system, though there are huge differences with the highest degree of progression being reported for Italy, with 16.3 percentage points, and the lowest one for Turkey, with only 2.2 percentage points.

Payroll taxes, reported in the fifth column, mainly consist of social security contributions paid by the employer. The average payroll tax progression, stated in the sixth

column, is very small, and even negative for some countries because of some work-related social-security contributions that are not dependent on wage income. While the maximum difference for the wage rate is above 16 percentage points, the differences for the payroll taxes are substantially lower in all countries, with a maximum below five percentage points. Thus, while we observe highly progressive wage tax systems, the payroll tax systems are approximately proportional.

\section{Model framework and comparative statics}

To start with, we specify the time sequence of decisions, and then, by using backward induction, analyze the decision of workers on their work effort, the optimal wage setting and labour demand of firms. Finally, based on these private decisions, we analyze two distinct revenue-neutral tax reforms that allow the government to alter the degree of tax progression. 


\subsection{Time sequence of decisions}

When firms decide on the wage rate $w$ they pay their workers and on the employment level, they take the tax policy as given and assume that they cannot influence the tax parameters. The government therefore behaves as a Stackelberg leader by setting three tax instruments. To raise revenues, the government can employ either a payroll tax $s$ or a wage tax $t$. Both tax rates are constant in relation to the respective tax base. In addition, the government can affect the degree of tax progression by granting a tax exemption $a$ that reduces the tax base for the wage rate $t$ to $(w-a) L$. In the presence of a positive tax exemption $a$, the marginal tax rate $t$ exceeds the average tax rate $t(1-a / w)$ so that the tax system is linearly progressive. ${ }^{2}$ The net-of-tax wage is given by $w^{n}=(1-t) w+t a$. While, according to table 1 , the wage taxes are progressive in all OECD countries, the payroll taxes, i.e. the social security contributions paid by employers, are approximately proportional. We therefore abstract from an additional tax exemption for the payroll tax so that the tax base for the payroll tax is $w L$. The gross wage rate, i.e. the labour cost, is then given by $w^{g}=w(1+s)$.

We can study two ways in which the government can alter tax progression without changing tax revenues. It can directly affect the wage tax progression by increasing the wage tax rate and increasing the tax exemption accordingly. Alternatively, it can increase the wage tax and lower the payroll tax. Such a change in the structure of labour taxation also affects the overall tax progression as it changes the shares of the progressive wage tax and the proportional payroll tax.

When the government announces its tax policy in the first stage, firms decide on the wage rate $w$ and the employment level $L$ in the $2^{\text {nd }}$ stage. In this process, they cannot perfectly monitor the individual work effort $e$ of their workers. As effort increases the disutility of working, workers have an incentive to shirk, but this incentive can be offset by paying higher wages since this raises the penalty for shirking workers who are caught and fired. On-the-job workers can decide upon their work effort in the $3^{\text {rd }}$ stage. The time sequence of decisions is

\footnotetext{
${ }^{2}$ For a seminal paper about tax progression, see Musgrave and Thin (1948), and for another elaboration, see e.g. Lambert (2001, chapters 7-8).
} 
shown in Figure 1. In what follows, we proceed by using backward induction and start our analysis with the $3^{\text {rd }}$ stage of the game, in which the wage rate, employment and tax parameters are already determined.

Figure 1: Sequence of decisions

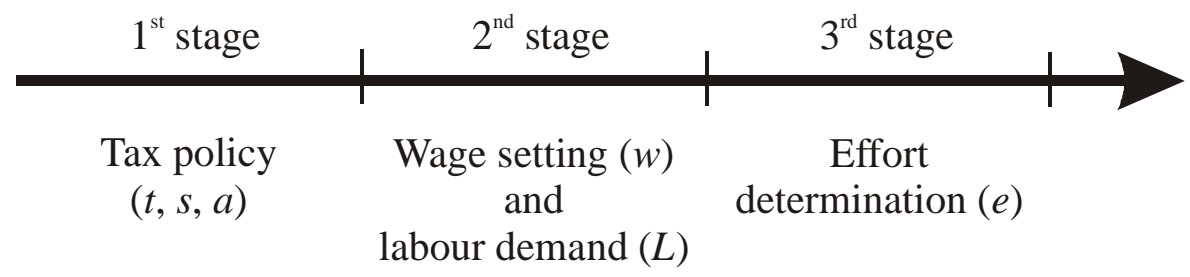

\subsection{Effort determination}

Each worker decides about effort $e$ in the $3^{\text {rd }}$ stage by taking the tax policy, wage setting and labour demand as given. Since effort cannot be fully controlled by firms, they can set a standard effort that we normalize to one. If workers meet this standard, their jobs are secure, but if they shirk by providing less effort, firms can fire them. However, effort cannot be monitored perfectly. The employment probability $\rho$ can thus be described by a minimum function. For effort lower than the standard, we assume, for analytical convenience, an isoelastic probability function of employment $\rho(e)=e^{d}$ where $d>0$ denotes the (constant) employment probability elasticity of effort. ${ }^{3}$ The employment probability rises with effort for $e<1$ and is 1 for a higher effort level, so that we have the employment probability function $\rho \equiv \min \left(1, e^{d}\right)$ and the probability of being laid off is $1-\min \left(1, e^{d}\right)$. The parameter $d$ is increasing in both monitoring intensity and monitoring efficiency. Low values of $d$ make it less risky for workers to shirk, while $d \rightarrow+\infty$ implies perfect monitoring and the firing of all workers who do not meet the working effort standard.

\footnotetext{
${ }^{3}$ We exclude the case where $d=0$ because in this case, the job would be secure even without providing effort and total output would fall to zero. This would lead firms to set a wage rate equal to zero. Both employment supply and demand would then be indetermined. Furthermore, note that if the detection probability should be concave in effort, we would have to assume $d \leq 1$.
} 
We consider a representative risk-neutral worker with a specific utility function $V^{w}$ that is additively separable and quasi-linear,

$$
V^{w}=\min \left(1, e^{d}\right)\left[w^{n}-g(e)\right]+\left(1-\min \left(1, e^{d}\right)\right) b,
$$

where $b$ denotes the workers' outside option, which equals some exogenous unemployment income, and $g(e)$ denotes the disutility of effort $e$ as a convex function, i.e. $g^{\prime}(e)>0, g^{\prime \prime}(e)>0 .{ }^{4}$ Working time per worker is fixed and normalized to unity.

The optimal individual effort level can be derived from the first-order condition $V_{e}^{w}=d e^{d-1}\left(w^{n}-g(e)-b\right)-e^{d} g^{\prime}(e)=0$. The worker chooses an effort level at which the expected utility loss of working harder, which occurs with probability $e^{d}$, equals the expected utility gain from an increased probability of staying in employment $d e^{d-1}$ and receiving the surplus $w^{n}-g(e)-b$. Using the parameterization $g(e)=\alpha e^{1 / \alpha}$ yields the following effort function

$$
e=A\left(w^{n}-b\right)^{\alpha},
$$

where $A=(d /(1+\alpha d))^{\alpha}$ is constant. We assume a concave effort function with respect to the difference between the net-of-tax wage rate and the workers' outside option so that we have $0<\alpha<1$. Effort is increasing in the net-of-tax wage rate, $e_{w^{n}}>0$, and decreasing in the outside option, $e_{b}<0$. Furthermore, we have $e_{t}<0$, because this reduces the penalty when caught shirking, $e_{w}>0$, and $e_{a}>0$, as both a higher wage rate $w$ and a higher tax exemption $a$ increase the rent from being employed. ${ }^{5}$

\subsection{Wage setting and labour demand}

In the $2^{\text {nd }}$ stage of the game, each firm takes the tax parameters as given and decides on the wage rate $w$ and labour demand $L$. In doing so, it takes into account how the representative

\footnotetext{
${ }^{4}$ In what follows, the derivatives of functions with one variable will be denoted by using primes, while partial derivatives will be denoted by subscripts indicating what variable we are differentiating with respect to.

${ }^{5}$ We could allow for a more general utility function that is concave in terms of rents and convex in terms of disutility of effort so that we could include risk aversion. Qualitative results by using the standard HARA-type utility function (suggested originally by Merton 1971) are similar and are available upon request.
} 
worker will adjust work effort when the wage rate $w$ changes. Production depends on effective labour input $e L$, so that the production function for the representative firm can be written as $f(e L)$ with $f^{\prime}(e L)>0$ and $f^{\prime \prime}(e L)<0$. The output price is normalized to unity and profits are defined by $\pi=f(e L)-w(1+s) L$. The first-order conditions in terms of $L$ and $w$ are $f^{\prime}(e L)=w(1+s) / e$ and $f^{\prime}(e L)=(1+s) / e_{w}$, so that we obtain the well-known Solow condition (Solow 1979)

$$
\frac{e_{w} w}{e}=1
$$

according to which the wage elasticity of effort is equal to one, i.e. the optimal wage is set such that a one percent increase in the wage rate (and thus the production costs) leads to a one percent increase in output (at a given employment level). From the Solow-condition (3) we can derive an explicit solution for the optimal efficiency wage rate for $e_{w}=\alpha(1-t) e(w(1-t)+t a-b)^{-1}>0:$

$$
w=\frac{b-t a}{(1-t)(1-\alpha)} .
$$

The comparative statics of the wage function shows that $\operatorname{sign}\left(w_{t}\right)=\operatorname{sign}(b-a)$ and $w_{a}<0$. The Solow condition states that it is optimal for the firm to set the wage such that the relative change in the wage rate is equal to the relative change in effort. If $b=a$, the level of $t$ has no effect on the optimal wage rate. If $b>a$, however, a tax rate increase raises the impact a wage rate increase has on effort: the higher $t$ is, the stronger the relative increase of $w^{n}-b$ due to a wage increase is. A higher tax exemption $a$, by contrast, makes working more attractive and therefore allows the firms to decrease the efficiency wage rate. Note that the payroll tax $s$ does not affect wage determination.

For the labour demand function, we use the parametric specification $f(e L)=\varepsilon^{-1}(e L)^{\varepsilon}$ with $0<\varepsilon<1$ denoting the revenue share of labour and $(1-\varepsilon)$, the profit share. The labour demand function is given by

$$
L=[w(1+s)]^{-\delta} e^{\delta-1},
$$


where $\delta \equiv 1 /(1-\varepsilon)>1$ and $\delta-1 \equiv \varepsilon /(1-\varepsilon)>\varepsilon$. The comparative statics of labour demand with

respect to effort and the payroll tax are $L_{e}=L(\delta-1) e^{-1}>0$ and $L_{s}=-\delta w[w(1+s)]^{-\delta-1} e^{\delta-1}=-\delta L(1+s)^{-1}<0$, respectively. The wage tax and the tax exemption - levied on workers - only affect labour demand indirectly via the effort determination, and the payroll tax only affects labour demand directly via the gross wage rate. The total effect of a change in the wage rate $w$, however, influences labour demand in two different ways. There is a negative direct effect, $L_{w}=-\delta L w^{-1}<0$, and a positive indirect effect of the wage rate via effort, $L_{e} e_{w}=(\delta-1)[w(1+s)]^{-\delta} e^{\delta-2}(\delta-1) e_{w}=(\delta-1) L e_{w} e^{-1}$. The former effect dominates, so that a higher wage rate $w$ decreases labour demand. For the concave production function, the absolute value of the wage elasticity of labour demand is lower than in the case when wages do not affect effort. Inserting the Solow condition, the total wage elasticity of labour demand in the firm’s profit maximum becomes

$$
\frac{d L}{d w} \frac{w}{L}=-1
$$

Effective labour input $e L$ and the wage bill $(1+s) w L$ remain constant due to a marginal wage increase and thus profit. This is a complementary condition to the Solow condition.

Having analyzed workers' and firms' behaviour with respect to changes in the tax parameters, we can now turn to the first stage. Rather than analyzing optimal tax systems, we consider small tax reforms in the first stage and focus on the effects of revenue-neutral changes in (i) wage tax progression (section 4) and (ii) the structure of labour taxation on wage formation, effort determination, employment and output (section 5).

\section{Revenue-neutral changes in wage tax progression}

We assume constant public expenditures of size $G$ so that a balanced budget requires

$$
G=[t(w-a)+s w] L .
$$


Tax progression increases when the difference between the total marginal tax wedge $t+s$ and the total average tax rate $(t+s)-t a / w$ increases. We call a revenue-neutral increase in both the wage tax rate $t$ and the tax exemption $a$ an increase in wage tax progression.

What is the combination of changes in the wage tax rate $t$ and the tax exemption $a$ combined with the incurred change in the wage rate $w$ that will keep government tax revenues constant? Total differentiation of (7) gives $d G=G_{t} d t+G_{a} d a+G_{w} d w=0$. Taking into account the induced change in the wage rate $d w=w_{t} d t+w_{a} d a$, this can be written as (see Appendix 1 for details)

$$
d G=\left(G_{t}+G_{w} w_{t}\right) d t+\left(G_{a}+G_{w} w_{a}\right) d a=0 .
$$

If we are on the upward-sloping part of the Dupuit-Laffer curve for both the wage tax rate and the tax exemption, meaning that the tax revenues increase in $t$ and decrease in $a$, we have $G_{t}+G_{w} w_{t}>0$ and $G_{a}+G_{w} w_{a}<0$. Since $G_{w}=t a L / w>0$ (see Appendix 1) and $w_{t}>0$ (assuming $b>a$ ), sufficient conditions for this to hold are $G_{t}>0$ and $G_{a}<0$.

\subsection{The effects on wages and effort}

Now we are prepared to explore the behavioural effects of tax revenue-neutral change in wage tax progression. After some calculating (delegated to Appendix 1), we obtain the effect of an increase in wage tax progression on the wage rate $w$ :

$$
\left.\frac{d w}{d t}\right|_{d G=0}=\frac{w_{t}+\frac{(w-a)}{t} w_{a}}{1+w_{a}\left(\frac{G_{w}}{G_{a}}\right)} .
$$

Due to our assumption of an upward-sloping Dupuit-Laffer curve, the denominator of (9) is positive. As for the numerator in (9), using the partial derivatives of (4) imply

$$
w_{t}+\frac{(w-a)}{t} w_{a}=\frac{(1-\alpha)(b-a)-(w-a)(1-t)(1-\alpha)}{(1-t)^{2}(1-\alpha)^{2}}=-\frac{\alpha w}{(1-t)(1-\alpha)}<0,
$$

so that we obtain an unambiguous wage moderation effect of raising tax progression: 


$$
\left.\frac{d w}{d t}\right|_{d G=0}<0
$$

If the firm lowers the wage rate, it benefits from lower wage costs but at the same time suffers from lower work effort, which reduces labour productivity. In the initial equilibrium, the firm sets the wage rate such that these two effects balance out at the margin. A revenue-neutral increase in wage tax progression implies that it becomes beneficial for firms to lower the wage rate because the effect on effort becomes smaller when the marginal tax rate increases.

To determine the impact on labour demand and work effort, we have to derive the change in the gross and net-of-tax wage rate, respectively. As we keep the payroll tax constant, a fall in the wage rate $w$ also lowers the gross wage rate $w(1+s)$. The change in the net-of-tax wage rate is given by:

$$
\left.\frac{d w^{n}}{d t}\right|_{d G=0}=-(w-a)+\left.t \frac{d a}{d t}\right|_{d G=0}+\left.(1-t) \frac{d w}{d t}\right|_{d G=0} .
$$

If the tax reform did not change the wage rate, increasing tax progression would leave the netof-tax wage rate unaffected. ${ }^{6}$ But when the wage rate falls, there are two negative effects on the net-of-tax wage rate. First, there is the immediate direct effect of wage moderation. Second, there is an indirect budgetary effect. As wage moderation lowers tax revenues, the government has to reduce the extent of the increase in the tax exemption $a$ relative to the potential increase $d w / d t$. This further reduces the net-of-tax wage rate, so that the total effect is unambiguously negative:

$$
\left.\frac{d w^{n}}{d t}\right|_{d G=0}=\left.\left[(1-t)-t \frac{G_{w}}{G_{a}}\right] \frac{d w}{d t}\right|_{d G=0}<0 .
$$

Effort depends positively on the net-of-tax wage, i.e. $e_{w^{n}}>0$, so that we can immediately deduce that workers' effort also falls:

$$
\left.\frac{d e}{d t}\right|_{d G=0}=\left.e_{w^{n}} \frac{d w^{n}}{d t}\right|_{d G=0}<0 .
$$

\footnotetext{
${ }^{6}$ This can be seen from substituting (A4) in (10) and setting $d w /\left.d t\right|_{d G=0}=0$.
} 
These findings are summarized in

Proposition 1: An increase in the revenue-neutral wage tax progression leads to wage moderation that reduces both the gross wage rate and the net-of-tax wage rate. A fall in the net-of-tax wage rate reduces individual work effort and thus negatively affects labour productivity.

\subsection{The effects on employment and output}

Labour demand depends both on the gross wage and effort. Firms will lower the gross wage but also face a lower labour productivity. Thus there are two countervailing effects on labour demand. From the total differential of employment $d L=\left(L_{w}+L_{e} e_{w}\right) d w+L_{e} e_{t} d t+L_{e} e_{a} d a$ and by using the revenue-neutral change in the tax exemption (7), we obtain

$$
d L=\left(L_{e} e_{t}-L_{e} e_{a} \frac{G_{t}}{G_{a}}\right) d t+\left(L_{w}+L_{e} e_{w}-L_{e} e_{a} \frac{G_{w}}{G_{a}}\right) d w .
$$

The first term equals the employment effect of a revenue-neutral tax reform when the wage rate does not change. This term is zero (see Appendix 2 for the calculations) because a revenue-neutral change in tax parameters without a change in the wage rate would not alter the net-of-tax wage rate. If the efficiency wage rate does not change, both effort and employment do not change. The employment effect thus only depends on the induced wage rate change, so that we have:

$$
\left.\frac{d L}{d t}\right|_{d G=0}=\left.\left(L_{w}+L_{e} e_{w}-L_{e} e_{a} \frac{G_{w}}{G_{a}}\right) \frac{d w}{d t}\right|_{d G=0} .
$$

To interpret this result and to sign the effect, we rewrite (13) in the following way:

$$
\left.\operatorname{sign} \frac{d L}{d t}\right|_{d G=0}=-\operatorname{sign}\left(\frac{L_{w}+L_{e} e_{w}}{L_{e} e_{a}}-\frac{G_{w}}{G_{a}}\right)=-\operatorname{sign}\left(\frac{\frac{d L}{d w}}{\frac{d L}{d a}}-\frac{G_{w}}{G_{a}}\right)=-\operatorname{sign}\left(-\frac{(1-t)}{(\delta-1) t}-\frac{G_{w}}{G_{a}}\right) .
$$

The first ratio indicates the relative impact the wage rate and the tax exemption have on employment. Let us assume that we increase the wage rate and the tax exemption by the same 
absolute amount, which we set equal to one percent of the initial wage rate. The effect of the wage rate, consisting of a direct effect via the gross wage and an opposing indirect effect via raising effort on employment, is then -1 . The change in the tax exemption only increases effort. However, the effect of an equal-size increase in the tax exemption on the net-of-tax wage rate is only $t /(1-t)$ of the effect of a wage rate increase. Multiplying by the effort elasticity of labour $(\delta-1)$ thus yields the total effect of the above increase in the tax exemption: $d L / d a \cdot w / L=(\delta-1) t /(1-t)$.

By how much can we actually change the wage rate and the tax exemption when we consider that revenue-neutrality depends on the marginal tax revenues? The higher the tax revenue of a tax parameter, the lower the respective adjustment in a revenue-neutral tax reform. If $G_{w}$ is large, which is the case the stronger the total tax wedge $s+t$ is, a low absolute value of $G_{a}$, which is the case when $t$ is low, requires a large reduction in the tax exemption to compensate for the induced effect.

The relative magnitudes can be seen best by inserting $-G_{w} / G_{a}=(t+s) / t$ in equation (13). This yields the following condition:

$$
\left.\frac{d L}{d t}\right|_{d G=0}\left\{\begin{array}{l}
> \\
= \\
<
\end{array}\right\} \quad \text { as } \frac{1-t}{(\delta-1) t}\left\{\begin{array}{l}
> \\
= \\
<
\end{array}\right\} \frac{t+s}{t} \Leftrightarrow \frac{1-t}{t+s}\left\{\begin{array}{l}
> \\
t \\
<
\end{array}\right\} \delta-1 .
$$

If the total tax wedge $s+t$ becomes very high, the wage moderating effect requires a higher downward adjustment of the tax exemption. If this already has a strong impact on effort (which depends on the technology parameter $(\delta-1)$ ), it becomes very likely that employment will fall. The adverse effect of tax progression on the budget adjustment requirements then outweigh the wage moderating effect on the gross wage.

The effects of the revenue-neutral change in the wage tax progression on effective labour input $e L$ and therefore on output are a priori unclear because an increase in tax progression has a negative effect on effort and an ambiguous effect on employment. The total differential for $(e L)$ is

$$
\left.\frac{d(e L)}{d t}\right|_{d G=0}=\left.\left(\left.L \frac{d e}{d t}\right|_{d G=0}+\left.e \frac{d L}{d t}\right|_{d G=0}\right) \cdot \frac{d w}{d t}\right|_{d G=0} .
$$


Solving (15) by using the results derived before (see Appendix 2), we obtain:

$$
\left.\frac{d(e L)}{d t}\right|_{d G=0}=-\left.\frac{G_{w}\left[e_{a}+L_{e} e_{a}\right]}{G_{a}} \cdot \frac{d w}{d t}\right|_{d G=0}<0 .
$$

The effort effect of higher tax progression is unambiguously negative, while the employment effect is a priori ambiguous but, according to equation (16), the first effect dominates. The direct effect of a wage rate change on labour demand would exactly compensate for lower work effort, but the indirect effect that forces the government to reduce the extent of the tax exemption increase further lowers effort, employment and, therefore, effective labour input.

In summing up the findings of this subsection, we can conclude with

Proposition 2: An increase in the revenue-neutral wage tax progression raises (lowers) employment when the ratio of net-of-tax wage and revenue share of the wage is higher (lower) than the effort elasticity of labour demand. Effective labor input and output fall unambiguously.

\section{Revenue-neutral changes in the composition of wage and payroll taxes}

In this section, we analyze the impacts of revenue-neutral changes in the composition of labour taxation on effort determination, wage formation, employment and output. This analysis has not yet been conducted within an efficiency framework, but it allows for a comparison with the results derived within a 'right-to-manage' union bargaining model. Koskela and Schöb (1999) demonstrate in such a framework that a revenue-neutral change in the composition of labour taxation affects neither the gross wage nor employment when the tax bases for the wage tax and payroll tax are equal. However, if there is a tax exemption for the wage tax, the tax base of the wage tax is narrower than in the case of proportional payroll taxes. In this case, a revenue-neutral tax reform which reduces the payroll tax rate and increases the wage tax rate will decrease the gross wage rate and thereby boost employment. Progression remains unchanged with the revenue-neutral change in labour taxes if the tax bases are equal, while a switch towards higher wage taxes and lower payroll taxes will make 
labour taxation more progressive and thus generate wage moderation if wage taxation is progressive due to a tax exemption.

To study the extent to which these results hold when efficiency wage considerations matter, we start with the identification of the respective tax reform and analyze the combination of changes in the tax rates and the wage rate which will keep government tax revenue constant. Taking the total differential of the government budget constraint (7) with respect to wage tax, payroll tax and gross efficiency wage gives $d G=G_{t} d t+G_{s} d s+G_{w} d w=0$. The change in the efficiency wage depends only on changes in the wage tax rate, $d w=w_{t} d t$, so that we have

$$
\left.\frac{d s}{d t}\right|_{d G=0}=-\frac{G_{t}+G_{w} w_{t}}{G_{s}} .
$$

If we are on the upward-sloping part of the Dupuit-Laffer curve, we have $G_{t}+G_{w} w_{t}>0$ (which always holds when $G_{t}>0$ and $b>a$ ) and $G_{s}>0$, so that a revenue-neutral increase in $t$ implies a lower payroll tax $s$.

\subsection{The effects on wages and effort}

The payroll tax borne by the employer does not affect the wage rate firms choose [cf. equation (4)]. The wage rate therefore is only affected by the wage tax rate, i.e.

$$
\left.\frac{d w}{d t}\right|_{d G=0}=w_{t}=\frac{b-a}{(1-t)^{2}(1-\alpha)} .
$$

A rise in $t$ unambiguously raises the wage rate when $b-a>0$, which is in line with empirical evidence. The total effect on the net-of-tax wage is given by $d w^{n}=-(w-a) d t+(1-t) d w$. Inserting this in equation (18), we obtain

$$
\left.\frac{d w^{n}}{d t}\right|_{d G=0}=-(w-a)+\frac{b-a}{(1-t)(1-\alpha)}=-\frac{\alpha a}{(1-\alpha)}\left\{\begin{array}{l}
< \\
=
\end{array}\right\} \text { if } a\left\{\begin{array}{l}
> \\
=
\end{array}\right\} 0 .
$$

Condition (19) indicates that the direct effect of a rise in the wage tax is not fully compensated by the indirect effect of a wage increase when there is a tax exemption, so that 
the tax incidence on firms is less than 100 percent. Therefore, a change in the structure of labour taxation only leads to a change in effort when there is a tax exemption, i.e.

$$
\left.\frac{d e}{d t}\right|_{d G=0}=\left.e_{w^{n}} \frac{d w^{n}}{d t}\right|_{d G=0}\left\{\begin{array}{l}
< \\
=
\end{array}\right\} 0 \text { if } a\left\{\begin{array}{l}
> \\
=
\end{array}\right\} 0 .
$$

This finding can be summarized in

Proposition 3: A revenue-neutral change in the composition of labour taxation that raises tax progression (i.e. $a>0$ ) lowers both the net-of-tax wage rate and effort. If the tax bases are the same (i.e. $a=0)$, the tax reform does not affect the net-of-tax wage rate and effort.

\subsection{The effects on employment and output}

The total differential of employment with respect to wage rate, payroll tax rate and wage tax rate can be written as $d L=\left(L_{w}+L_{e} e_{w}\right) d w+L_{e} e_{t} d t+L_{s} d s$. By using the revenue-neutral change in labour taxation (17), we obtain

$$
d L=\left(L_{e} e_{t}-L_{s} \frac{G_{t}}{G_{s}}\right) d t+\left(L_{w}+L_{e} e_{w}-L_{s} \frac{G_{w}}{G_{s}} w_{t}\right) d w .
$$

A change in the composition of wage and payroll taxes leads to both direct and indirect effects. The two direct effects reinforce each other. Both the increase in $t$ and $w$ (note that we have $d w=w_{t} d t$ ) will have a negative net effect on labour demand. The indirect effects work via the government budget. The term $G_{t} / G_{s}$ is the weight of the positive direct effect $-L_{s}$ in the first bracket term and determines how much the effect due to an increase in $t$ is offset. Since the wage rate also increases, the second indirect effect works in exactly the same qualitative way as the first indirect effect, whereby $G_{w} / G_{s}$ in the second bracket term is the weight of the positive indirect effect $-L_{s}$.

It turns out that the conditions for the sign of the two bracket terms are the same and depend on the same relationship between tax parameters and the constant-effort labour 
demand elasticity as the employment effect of an increase in wage tax progression, i.e. (see Appendix 3 for the calculations)

$$
\left.\frac{d L}{d t}\right|_{d G=0}\left\{\begin{array}{l}
> \\
= \\
<
\end{array}\right\} 0 \text { if } \quad a>0 \text { and } \frac{1-t}{t+s}\left\{\begin{array}{l}
> \\
= \\
<
\end{array}\right\} \delta-1 .
$$

Finally, we investigate the effect of a change in the labour tax structure on the effective labour input $e L$ and, at the same time, on output. For $a>0$, the total differential for $(e L)$ is

$$
\left.\frac{d(e L)}{d t}\right|_{d G=0}=\left.(\underbrace{\left.L \frac{d e}{d t}\right|_{d G=0}+\left.e \frac{d L}{d t}\right|_{d G=0}}_{-}) \underbrace{\frac{d w}{d t}}_{+}\right|_{d G=0}<0
$$

(see Appendix 4 for calculations). Irrespective of the way in which tax progression is raised, it may happen that although employment increases when tax progression increases, effective labour input and thus output will fall. If the tax bases are equal, i.e. $a=0$, neither effort nor labour is affected by the revenue-neutral change in the composition of wage and payroll taxes. This means that effective input and, therefore, output are not affected either.

We can summarize this finding in

Proposition 4: A revenue-neutral change in the composition of labour taxation that raises tax progression (i.e. $a>0$ ) increases (decreases) employment when the ratio of the net-of-tax wage and the revenue share of the wage is higher (lower) than the effort elasticity of labour demand. Effective labour input and output fall unambiguously. When the tax bases are equal, effort, employment and output do not change.

The intuition for $a>0$ is similar to the intuition for Proposition 2 and will not be repeated here. This result shows that in the case of equal tax bases, the structure of labour taxation does not matter in terms of employment in the efficiency wage framework. The same result holds in the union bargaining framework without efficiency considerations (see Koskela and Schöb 1999). Furthermore, both tax reforms increase tax progression and yield similar effects with respect to effort, labour demand, effective labour input and output. This indicates a systematic pattern of how the degree of tax progression actually affects the labour market and production. 


\section{Concluding remarks}

The structure of labour taxes, i.e. payroll and wage taxes, in OECD countries varies considerably due to different tax rates and different regulations concerning tax allowances and tax credits with respect to wage and payroll taxes. Wage taxation in OCED countries is progressive, although the degree of progressivity varies across countries. In the case of payroll taxes, the difference between marginal and average payroll taxes is very small, i.e. we observe approximately proportional payroll tax systems in most OECD countries. For these stylized facts, we studied the impacts of two different tax-revenue-neutral changes in wage tax progression. First, we analyzed the revenue-neutral tax reform where both the wage tax rate and the tax exemption were increased so that wage tax progression increased. Second, we compared these findings with a rise in tax progression due to a change in the composition of labour taxation towards the tax with the lower tax base.

Our analysis shows that when the wage tax system becomes more progressive, this leads to wage moderation and to a fall in workers' effort. Whether employment rises or falls depends on the pre-existing tax system relative to the labour demand elasticity in terms of work effort (see equations (14), (22)) because the magnitude of the total tax wedge affects the way in which the government can influence workers' effort in a revenue-neutral way. The increase in the wage tax ceteris paribus raises the gross wage and lowers labor demand. The larger the tax wedge, the greater the fall in tax revenues due to the induced wage moderation and the smaller the revenue-neutral rise in the tax exemption or the cut in payroll taxes, which ceteris paribus both increase labor demand. This budgetary effect is the driving force in both tax reforms discussed in this paper. In contrast to the interpretation of an increase in employment in trade union models, the rise in employment does not imply a rise in output. The opposite is in fact true. Since effort decreases, we have an countervailing effect on effective labor input, which in turn leads to an unambiguous decline in output. 


\section{Appendix 1}

The total differential for (6) gives $d G=G_{t} d t+G_{a} d a+G_{w} d w=0$. Using

$$
G_{w}=\left[t+s+(t w-t a+s w) \frac{\left(L_{w}+L_{e} e_{w}\right)}{L}\right] L=\frac{t a}{w} L>0,
$$

we can write the total differential as $d G=0 \Leftrightarrow G_{t} d t+G_{a} d a+\operatorname{taw}^{-1} L d w=0$. Inserting the respective partial derivatives of labor and effort, applying $e_{t} t=-(w-a) e_{a}$ and assuming that the tax revenues are positively related to the wage tax rate and negatively related to the tax exemption according to the upward-sloping Dupuit-Laffer curve, we can determine the sign of $G_{t}$ and $G_{w}$ as follows:

$$
G_{t}=L\left[w-a+\left(w-a+\frac{s}{t} w\right) \frac{L_{e} e_{t} t}{L}\right]=L\left[w-a+\left(w-a+\frac{s}{t} w\right) \frac{(\delta-1) e_{t} t}{e}\right]>0,
$$

$$
G_{a}=t L\left[-1+\left(w-a+\frac{s}{t} w\right) \frac{L_{e} e_{a}}{L}\right]=\frac{-t}{(w-a)} G_{t}<0
$$

Using the expressions (A2) and (A3), we can now determine the revenue-neutral change in the tax exemption when the wage tax rate is increased marginally:

$$
\left.d a\right|_{d G=0}=\left(\frac{w-a}{t}\right) d t-\frac{G_{w}}{G_{a}} d w .
$$

Substituting the RHS of (A4) for $d a$ in the total differential $d w=w_{t} d t+w_{a} d a$ yields (9).

\section{Appendix 2}

Substituting (A4) for $d a$ in the total differential $d L=\left(L_{w}+L_{e} e_{w}\right) d w+L_{e} e_{t} d t+L_{e} e_{a} d a$ gives

$$
\left.\frac{d L}{d t}\right|_{d G=0}=L_{e} e_{t}+\frac{(w-a)}{t} L_{e} e_{a}+\left(L_{w}+L_{e} e_{w}-\frac{L_{e} e_{a} G_{w}}{G_{a}}\right)\left(\left.\frac{d w}{d t}\right|_{d \bar{G}=0}\right) .
$$

Using the partial derivatives of the employment and effort functions, we obtain

$$
L_{e} e_{t}+\frac{(w-a)}{t} L_{e} e_{a}=\frac{L(\delta-1)}{e}\left[e_{t}+\frac{(w-a)}{t} e_{a}\right]=0 \text {. }
$$

Using (A1) and (A3), we obtain after some further manipulations 
(A6)

$$
\left.\frac{d L}{d t}\right|_{d G=0}=-\frac{L}{w}\left(\frac{e-w\left(1+\frac{s}{t}\right)(\delta-1) e_{a}}{e-w\left(1+\frac{s}{t}\right)(\delta-1) e_{a}+a(\delta-1) e_{a}}\right)\left(\left.\frac{d w}{d t}\right|_{d \bar{G}=0}\right)
$$

where $e-w(1+s / t)(\delta-1) e_{a}+a(\delta-1) e_{a}=-e G_{a}>0$. From the effort determination (2) we have $e-w(1+s / t)(\delta-1) e_{a}=e\left[w^{n}-b\right]^{-1}[w(1-t)+t a-b-w(t+s) \alpha(\delta-1)]$ so that

$$
\left.\frac{d L}{d t}\right|_{d G=0}\left\{\begin{array}{l}
> \\
= \\
<
\end{array}\right\} \text { as } w(1-t)+t a-b\left\{\begin{array}{l}
> \\
= \\
<
\end{array}\right\} w(t+s) \alpha(\delta-1) .
$$

Substituting the efficiency wage equation (4) for $w$ in (A7) gives condition (14).

Using the equations (11) and (A5), we can rewrite (15) as follows (using $\left.e_{w^{n}}=e_{w}(1-t)^{-1}=e_{a} t^{-1}\right)$

$$
\left.\frac{d(e L)}{d t}\right|_{d G=0}=\left\{L\left(e_{w}-\frac{e_{a} G_{w}}{G_{a}}\right)+e\left(L_{w}+L_{e} e_{w}-L_{e} e_{a} \frac{G_{w}}{G_{a}}\right)\right\}\left(\frac{d w}{d t}\right)_{d G=0}
$$

Using partial derivatives of the employment and effort functions, the common term $L e_{w}+e\left(L_{w}+L_{e} e_{w}\right)$ can be written as

$$
L e_{w}+e\left(L_{w}+L_{e} e_{w}\right)=\frac{e L}{w}\left[\frac{e_{w} w}{w}+\frac{d L}{d w} \frac{w}{L}\right]=0 .
$$

Inserting these, we obtain condition (16).

\section{Appendix 3}

Taking the total differential of government budget constraint (6) with respect to wage tax, payroll tax and gross efficiency wage gives $d G=0=G_{t} d t+G_{s} d s+G_{w} d w$, whereby

$$
G_{s}=L\left[w+(t(w-a)+s w) \frac{L_{s}}{L}\right]
$$

Using $\frac{L_{s}}{L}=-\frac{\delta}{1+S}$, we obtain for the first term of the RHS of equation (21)

$$
\left(L_{e} e_{t}-L_{s} \frac{G_{t}}{G_{s}}\right)=\left[1-(t+s-(t a / w)) \frac{\delta}{1+s}\right]^{-1} \frac{L(w-a)}{w(1+s)(1-t)}[1+s-(t+s) \delta]
$$

The second RHS term of equation (21) is

$$
\left(L_{w}+L_{e} e_{w}-L_{s} \frac{G_{w}}{G_{s}} w_{t}\right)=\left[1-(t+s-(t a / w)) \frac{\delta}{1+s}\right]^{-1}\left(-\frac{L}{w(1+s)}[1+s-(t+s) \delta]\right) .
$$


Using equation (18) implies

$$
\left(L_{w}+L_{e} e_{w}-L_{s} \frac{G_{w}}{G_{s}}\right)\left(\left.\frac{d w}{d t}\right|_{d G=0}\right)=
$$

(A12)

$$
\begin{aligned}
& {\left[1-(t+s-(t a / w)) \frac{\delta}{1+s}\right]^{-1}\left(-\frac{L}{w(1+s)}[1+s-(t+s) \delta]\right)\left(\left.\frac{d w}{d t}\right|_{d G=0}\right)=} \\
& {\left[1-\left(t+s-(t a / w) \frac{\delta}{1+s}\right]^{-1}\left(-\frac{L[1+s-(t+s) \delta]}{w(1+s)(1-t)}\left(w-\frac{a}{1-\alpha}\right)\right)\right.}
\end{aligned}
$$

Finally, combining (A10) and (A12) yields

(A13) $\left.\operatorname{sign} \frac{d L}{d t}\right|_{d G=0}=\operatorname{sign}\left(\frac{L[1+s-(t+s) \delta]}{w(1+s)(1-t)} \frac{a \alpha}{1-\alpha}\right)=\operatorname{sign}[1+s-(t+s) \delta]$, as $a>0$.

This gives the conditions of (22).

\section{Appendix 4}

Concerning equation (23) we have

$$
\left.L \frac{d e}{d t}\right|_{d G=0}=-\frac{\alpha e L}{w^{n}-b} \frac{\alpha a}{1-a}=-\frac{e L}{w(1-t)} \frac{\alpha a}{1-a}<0 .
$$

Finally, we have

(A15) $\left.L \frac{d e}{d t}\right|_{d G=0}+\left.e \frac{d L}{d t}\right|_{d G=0}=\frac{e L}{w(1-t)} \frac{\alpha a}{1-a}\left[\frac{1+s-(t+s) \delta}{1+s-(t+s) \delta+(t a / w) \delta}-1\right]<0$ as $a>0$. 


\section{References}

Andersen, T. M., Rasmussen, B. S. (1999): Effort, taxation and unemployment, Economics Letters 62, 97-103.

Fuest, C. and B. Huber (1998): Efficiency wages, employment, and the marginal income-tax rate: A note, Journal of Economics 68, 79-84.

Goerke, L. (1999): Efficiency wages and taxes, Australian Economic Papers 38, 131-142.

Heijdra, B.J. and J.E. Lighart (2005): Labor tax reform and equilibrium unemployment: a search and matching approach, mimeo, revised in September 2005.

Hoel, M. (1990): Efficiency wages and income taxation, Journal of Economics 51, 89-99.

Holm, P. and Koskela, E. (1996): Tax progression, structure of labour taxation and employment, FinanzArchiv 53, 28-46.

Koskela, E. and R. Schöb (1999): Does the composition of wage and payroll taxes matter under Nash bargaining?, Economics Letters 64, 343-349.

Koskela, E. and R. Schöb (2002): Why governments should tax mobile capital in the presence of unemployment?, Contributions of Economic Analysis \& Policy 1, Article 1.

Koskela, E. and J. Vilmunen (1996): Tax progression is good for employment in popular models of trade union behaviour, Labour Economics 3, 65-80.

Lambert, P. J. (2001): The distribution and redistribution of income, $3^{\text {rd }}$ edition, Manchester University Press.

Merton, R. (1971): Optimum consumption and portfolio rules in a continuous-time model, Journal of Economic Theory 3, 373-413.

Musgrave, R. A. and T. Thin (1948): Income tax progression, 1929-1948, Journal of Political Economy 56, 498-514.

OECD (2004): Taxing Wages 2003-2004, OECD Paris.

Picard, P. M. and E. Toulemonde (2003): Taxation and labour markets, Journal of Economics 78, 29-56.

Pissarides, C. A. (1998): The impact of employment tax cuts on unemployment and wages: the role of unemployment benefits and tax structure, European Economics Review 42, 155 183.

Rasmussen, B. S. (2002): Efficiency wages and the long-run incidence of progressive taxation, Journal of Economics 76, 155-175.

Shapiro, C. and J. E. Stiglitz (1984): Equilibrium unemployment as a worker discipline device, American Economic Review 74, 433-444.

Solow, R. M. (1979): Another possible source of wage stickiness, Journal of Macroeconomics 1, 79-82.

Sorensen, P. B. (1999): Optimal tax progressivity in imperfect labour markets, Labour Economics 6, 435-452. 